\title{
Article \\ Thermal Stability of Potassium-Promoted Cobalt Molybdenum Nitride Catalysts for Ammonia Synthesis
}

\author{
Paweł Adamski * (D), Wojciech Czerwonko and Dariusz Moszyński (D) \\ Department of Inorganic Chemical Technology and Environment Engineering, Faculty of Chemical Technology \\ and Engineering, West Pomeranian University of Technology in Szczecin, Piastów Ave. 42, \\ 71-065 Szczecin, Poland; wojciech.czerwonko@zut.edu.pl (W.C.); dmoszynski@zut.edu.pl or \\ dariusz.moszynski@zut.edu.pl (D.M.) \\ * Correspondence: adamski_pawel@zut.edu.pl; Tel.: +48-91-449-4024
}

check for updates

Citation: Adamski, P.; Czerwonko, W.; Moszyński, D. Thermal Stability of Potassium-Promoted Cobalt

Molybdenum Nitride Catalysts for Ammonia Synthesis. Catalysts 2022, 12, 100. https://doi.org/ $10.3390 /$ catal12010100

Academic Editor: Marco Martino

Received: 22 December 2021

Accepted: 14 January 2022

Published: 16 January 2022

Publisher's Note: MDPI stays neutral with regard to jurisdictional claims in published maps and institutional affiliations.

Copyright: (C) 2022 by the authors. Licensee MDPI, Basel, Switzerland. This article is an open access article distributed under the terms and conditions of the Creative Commons Attribution (CC BY) license (https:// creativecommons.org/licenses/by/ $4.0 /)$.

\begin{abstract}
The application of cobalt molybdenum nitrides as ammonia synthesis catalysts requires further development of the optimal promoter system, which enhances not only the activity but also the stability of the catalysts. To do so, elucidating the influence of the addition of alkali metals on the structural properties of the catalysts is essential. In this study, potassium-promoted cobalt molybdenum nitrides were synthesized by impregnation of the precursor $\mathrm{CoMoO}_{4} \cdot 3 / 4 \mathrm{H}_{2} \mathrm{O}$ with aqueous $\mathrm{KNO}_{3}$ solution followed by ammonolysis. The catalysts were characterized with the use of XRD and BET methods, under two conditions: as obtained and after the thermal stability test. The catalytic activity in the synthesis of ammonia was examined at $450{ }^{\circ} \mathrm{C}$, under $10 \mathrm{MPa}$. The thermal stability test was carried out by heating at $650{ }^{\circ} \mathrm{C}$ in the same apparatus. As a result of ammonolysis, mixtures of two phases: $\mathrm{Co}_{3} \mathrm{Mo}_{3} \mathrm{~N}$ and $\mathrm{Co}_{2} \mathrm{Mo}_{3} \mathrm{~N}$ were obtained. The phase concentrations were affected by potassium admixture. The catalytical activity increased for the most active catalyst by approximately 50\% compared to non-promoted cobalt molybdenum nitrides. The thermal stability test resulted in a loss of activity, on average, of $30 \%$. Deactivation was caused by the collapse of the porous structure, which is attributed to the conversion of the $\mathrm{Co}_{2} \mathrm{Mo}_{3} \mathrm{~N}$ phase to the $\mathrm{Co}_{3} \mathrm{Mo}_{3} \mathrm{~N}$ phase.
\end{abstract}

Keywords: cobalt molybdenum nitrides; ammonia synthesis; phase composition; specific surface area

\section{Introduction}

The Haber-Bosch process developed in the early years of the twentieth century had a great influence on the production of ammonia. This process uses an iron catalyst that allows direct bonding of $\mathrm{H}_{2}$ and $\mathrm{N}_{2}$ and can be considered efficient; however, due to the huge worldwide production of ammonia, the continuous improvement of catalysts is required for both financial and environmental reasons [1]. An important approach to solving this problem was the application of ruthenium-based catalysts. They exhibit high activity in ammonia synthesis but are burdened by several technological flaws, as well as high cost $[2,3]$. These led researchers to focus on less expensive and more available materials instead of noble metal-based catalysts [4]. Transition metal nitrides proved to be very effective catalysts that can be obtained as binary [5], ternary [1] and very recently quaternary [6] systems that-with further improvements-can serve as excellent catalysts for ammonia synthesis.

Ternary transition metal nitrides are well-known catalysts for hydrogenation reactions such as hydrosulfurization of thioorganic compounds [7-9], hydroprocessing of organic compounds [10] hydrazine decomposition [11] and NO reduction [12]. For ammonia synthesis, theoretical studies indicate that cobalt molybdenum nitride is the most active among the other chemical substances $[13,14]$.

The studies of cobalt molybdenum nitride promoted by alkali metals were carried out by Kojima and Aika [15]. During these studies, a substantial increase in the catalytic activity, caused by the presence of cesium or potassium in the catalyst, was observed. A specific 
concentration of each of the promoters was required to obtain the optimal catalytic activity. The cesium promoter was found to be more effective compared to potassium [16]. The proposed beneficiary effect of alkali metals on catalyst activity was described in the terms of changes in the electronic properties of the active sites through the electron-donation mechanism [17]. However, studies of other catalytical systems suggest that the effect of the addition of alkali metals is more complicated.

A structural effect of promoter addition was observed in cobalt molybdenum nitride catalysts. In our previous studies $[18,19]$ we reported the complexity of the phase composition of the cobalt molybdenum nitride catalysts, especially the occurrence of two active phases: $\mathrm{Co}_{2} \mathrm{Mo}_{3} \mathrm{~N}$ and $\mathrm{Co}_{3} \mathrm{Mo}_{3} \mathrm{~N}$. Their concentration ratio varies with the type and concentration of the applied promoters. Cobalt molybdenum nitride catalysts promoted with chromium $[19,20]$ as well as potassium and chromium [21] were compared. The chromium admixture was found to hinder, and potassium to facilitate the formation of the $\mathrm{Co}_{2} \mathrm{Mo}_{3} \mathrm{~N}$ phase. The mechanism that leads to the coexistence of the $\mathrm{Co}_{2} \mathrm{Mo}_{3} \mathrm{~N}$ and $\mathrm{Co}_{3} \mathrm{Mo}_{3} \mathrm{~N}$ phases was studied in detail elsewhere [22]. The $\mathrm{Co}_{2} \mathrm{Mo}_{3} \mathrm{~N}$ phase was shown to be an intermediate phase in the formation of the $\mathrm{Co}_{3} \mathrm{Mo}_{3} \mathrm{~N}$ phase. Catalysts with higher concentrations of the $\mathrm{Co}_{2} \mathrm{Mo}_{3} \mathrm{~N}$ phase are catalytically more active $[18,19]$.

In addition to the catalytical activity, an important factor for the practical application of catalysts is their thermal stability. Each catalyst changes in the course of the reaction, and its deactivation occurs. For an industrial application, the interval between loads of fresh catalyst should be as long as possible, for example, for the iron catalyst, it is about ten years [23]. In the case of cobalt molybdenum nitrides, the available information about stability during prolonged test runs is limited. The stability of the catalytic properties was examined in detail for the non-promoted and cesium-promoted catalysts by Kojima and Aika [24]. It was shown that during the $24 \mathrm{~h}$ process under the atmosphere of the reaction gas $\mathrm{N}_{2}+3 \mathrm{H}_{2}$ at $600{ }^{\circ} \mathrm{C}$, both the unpromoted catalyst and the Cs-promoted catalysts reached the maximum of their activity after $12 \mathrm{~h}$. Subsequently, their activity gradually decreased. At the same time, their BET surface area decreased by approximately half. The increase in activity was associated with the transformation of the intermediate $\mathrm{Co}$ and $\mathrm{Mo}_{2} \mathrm{~N}$ phases into the $\mathrm{Co}_{3} \mathrm{Mo}_{3} \mathrm{~N}$ phase.

The stability of the unpromoted cobalt molybdenum nitride catalyst was examined via in situ XRD studies [25]. The phase concentrations of $\mathrm{Co}_{2} \mathrm{Mo}_{3} \mathrm{~N}$ and $\mathrm{Co}_{3} \mathrm{Mo}_{3} \mathrm{~N}$ under a reaction gas atmosphere at $700{ }^{\circ} \mathrm{C}$ were stable. The $\mathrm{Co}_{3} \mathrm{Mo}_{3} \mathrm{~N}$ phase decomposed into the $\mathrm{Co}_{6} \mathrm{Mo}_{6} \mathrm{~N}$ phase under a hydrogen atmosphere. This transformation was explained in terms of the high reactivity of bulk lattice nitrogen present in $\eta$-carbide structured $\mathrm{Co}_{3} \mathrm{Mo}_{3} \mathrm{~N}$ by Daisley et al. [26].

The outlook on the behavior under industrial reaction conditions of non-promoted and $\mathrm{K}, \mathrm{Cs}$, Cr-promoted catalysts before and after thermostability test was given by Nadziejko et al. [27]. It was shown that the specific surface area and activity of the Cspromoted catalysts after the thermostability test decreased the most among the studied catalysts. A serious deactivation for Cs-promoted catalysts was also observed by us, in a detailed study [28]. It was associated with the sintering of the crystallites of the active phases and decreasing of the surface area of the catalysts. Furthermore, in the study of Boisen et al. [5] the influence between the activity of the Cs-promoted catalyst and its surface area was observed. Despite their initial high activity, Cs-promoted catalysts are regarded as highly prone to sintering and are inefficient in the long run.

There are still ambiguities regarding the influence of alkali metals on ammonia synthesis catalysts. In addition to electron transfer from the alkali to the active center, other factors such as the change of surface structure or change of the crystallite sizes must be considered. To address this problem in the present study, the thermal stability of the K-promoted catalyst was examined in detail. Cobalt molybdenum nitrides promoted by potassium were studied as catalysts in ammonia synthesis at $450{ }^{\circ} \mathrm{C}$ and subsequently after prolonged heating under a $\mathrm{H}_{2}-\mathrm{N}_{2}$ gas mixture at $650{ }^{\circ} \mathrm{C}$. The transformation of the phase 
structure, porous structure, and catalytic activity of the examined catalysts were related to the concentration of potassium in the catalytic material.

\section{Results}

Cobalt molybdenum nitride catalysts modified with an admixture of potassium (henceforth abbreviated as COMON catalysts), were obtained in a three-step process. First, the precipitation of cobalt molybdates, referred to as precursors, was carried out. The precipitation of precursors was followed by their impregnation with the potassium nitrate. Subsequently, the activation process of the catalyst precursors was performed under the flow of pure ammonia (a process called ammonolysis). The obtained catalysts were studied in two chemical states: after ammonolysis of the precursors, and after the activity measurements followed by the aging of the catalysts under increased temperature. More detailed experimental conditions are described in the Section 4.

The X-ray diffraction pattern of the synthesized precursor is consistent with previously published results [20], where the precursor was identified as $\mathrm{CoMoO}_{4} \cdot 3 / 4 \mathrm{H}_{2} \mathrm{O}(\mathrm{PDF} 04$ 011-8282). In Figure 1, the XRD pattern acquired after ammonolysis is shown for the exemplary sample containing $0.2 \mathrm{wt}$. \% of potassium. The diffraction reflections observed for the catalysts after ammonolysis, as well as after thermal stability tests, were ascribed exclusively to $\mathrm{Co}_{3} \mathrm{Mo}_{3} \mathrm{~N}$ or $\mathrm{Co}_{2} \mathrm{Mo}_{3} \mathrm{~N}$ phases. No oxidic phases, metallic cobalt or $\mathrm{Mo}_{2} \mathrm{~N}$ were detected, although the surface of all samples after each process was passivated in diluted oxygen prior to XRD analysis.

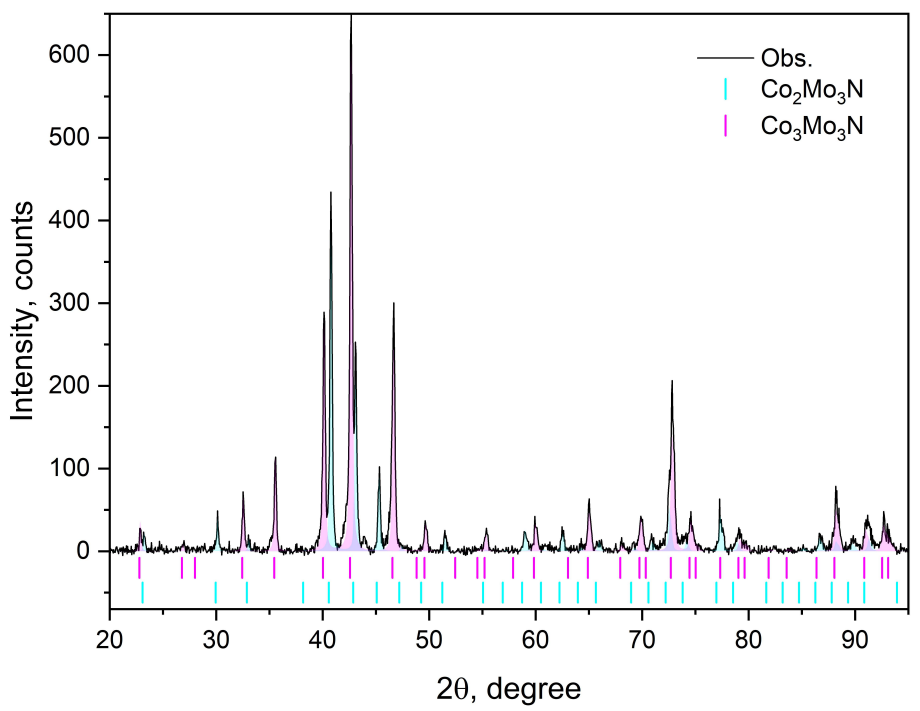

Figure 1. X-ray diffraction pattern of the COMON catalyst containing $0.2 \mathrm{wt} . \%$ of potassium acquired after ammonolysis, with the indicated Rietveld refinement.

The weight fractions of the $\mathrm{Co}_{2} \mathrm{Mo}_{3} \mathrm{~N}$ (PDF 04-010-6426) and $\mathrm{Co}_{3} \mathrm{Mo}_{3} \mathrm{~N}$ (PDF 04-0081301) phases identified in the catalysts were determined by $X$-ray diffraction analysis with the use of Rietveld refinement. The weight fraction of the $\mathrm{Co}_{2} \mathrm{Mo}_{3} \mathrm{~N}$ phase related to the potassium concentration is shown in Figure 2. The $\mathrm{Co}_{3} \mathrm{Mo}_{3} \mathrm{~N}$ phase complements the composition of the catalysts. The non-promoted sample contains about $18 \mathrm{wt} \%$ of the cobalt-lean $\mathrm{Co}_{2} \mathrm{Mo}_{3} \mathrm{~N}$ phase. The content of this phase in the catalyst grows to about $47 \mathrm{wt}$ \% \% with increasing potassium concentration to top at $0.8 \mathrm{wt} . \%$. At even higher potassium concentrations, a decrease in $\mathrm{Co}_{2} \mathrm{Mo}_{3} \mathrm{~N}$ concentration is observed. At a potassium concentration of $3.5 \mathrm{wt} . \%$, the $\mathrm{Co}_{2} \mathrm{Mo}_{3} \mathrm{~N}$ concentration dropped to $18 \mathrm{wt}$. $\%$ of the catalyst. 


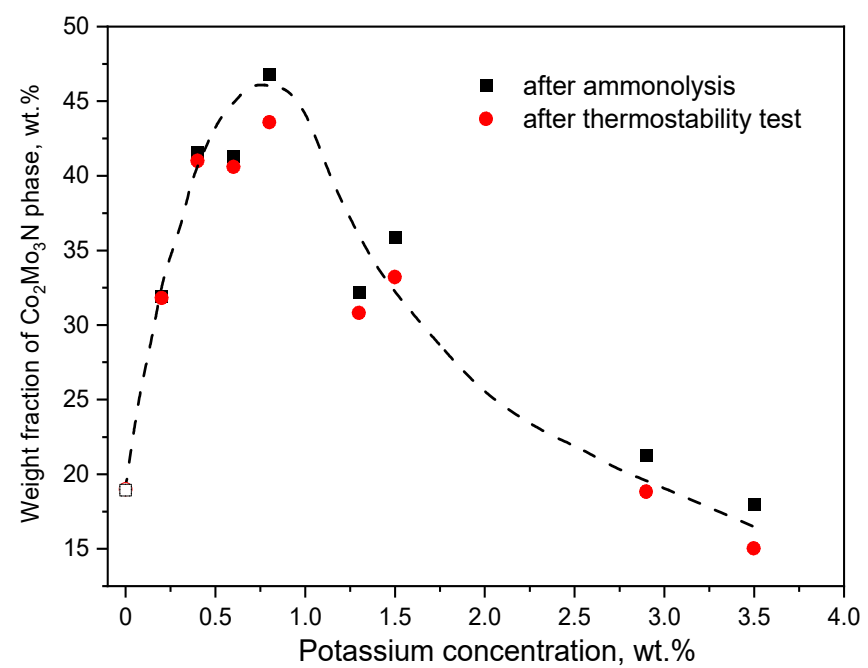

Figure 2. Weight fraction of the $\mathrm{Co}_{2} \mathrm{Mo}_{3} \mathrm{~N}$ phase as a function of potassium concentration in COMON catalysts. A line is given for eye guidance.

The catalysts after the thermal stability tests were also subjected to a diffraction analysis, as presented in Figure 2. In general, the relation between the weight fraction of the $\mathrm{Co}_{2} \mathrm{Mo}_{3} \mathrm{~N}$ phase and the potassium concentration is similar to that observed for these materials before aging. For the non-promoted catalyst, the share of the $\mathrm{Co}_{2} \mathrm{Mo}_{3} \mathrm{~N}$ phase after the aging process was unchanged. However, for the promoted catalysts, the phase composition of the samples changed slightly after the thermostability test and the weight fraction of the $\mathrm{Co}_{2} \mathrm{Mo}_{3} \mathrm{~N}$ phase was reduced for all promoted catalysts.

The specific surface area is an important factor that influences the catalytic properties of the catalysts. During the present study, this parameter was measured twice for all of the catalysts: after ammonolysis and after thermostability test. The results are depicted in Figure 3. The specific surface area of fresh, non-promoted COMON catalyst is $15.5 \mathrm{~m}^{2} / \mathrm{g}$, a value typical for many carrier-free metallic catalysts $[29,30]$. The surface area of the remaining catalysts depends on the concentration of potassium. It amounted to $9.2 \mathrm{~m}^{2} / \mathrm{g}$ for the fresh catalyst containing $0.2 \mathrm{wt} . \%$ of potassium and increased in the range of potassium concentration between $0.4 \mathrm{wt} . \%$ and $0.8 \mathrm{wt} . \%$. The maximum was observed at $0.8 \mathrm{wt} . \%$ of potassium and amounted to $10.7 \mathrm{~m}^{2} / \mathrm{g}$. A further increase of potassium concentration resulted in a decrease in the specific surface area. The most prominent loss was observed for catalysts containing $2.9 \mathrm{wt} . \%$ and $3.5 \mathrm{wt} . \%$ of potassium, where the specific surface area measured was approximately $5.5 \mathrm{~m}^{2} / \mathrm{g}$.

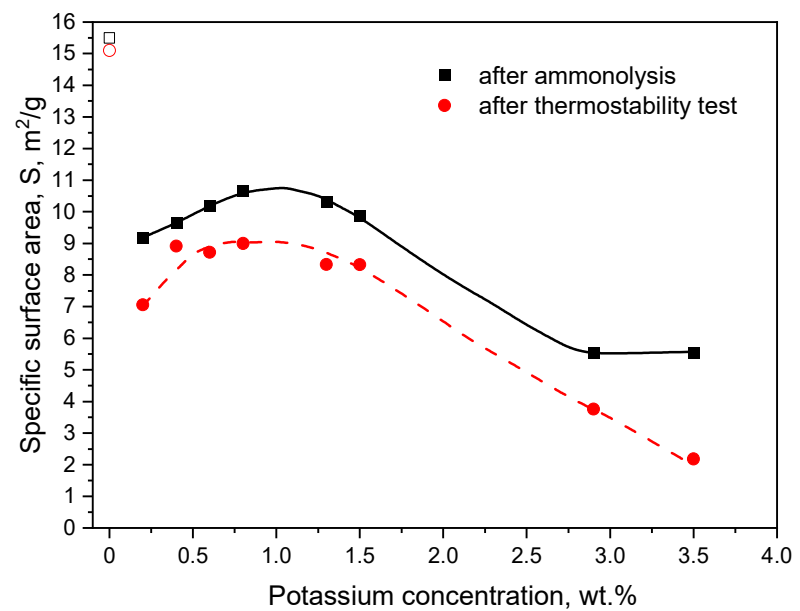

Figure 3. Specific surface area of COMON catalysts as a function of potassium concentration, measured after ammonolysis and after all catalytic tests. Lines are given for eye guidance. 
After thermostability tests, a drop in surface area was observed for all catalysts. In the case of the non-promoted COMON catalyst the surface area decreased insignificantly to $15.0 \mathrm{~m}^{2} / \mathrm{g}$. The loss was much more noticeable for COMON catalysts promoted with potassium compounds. For all of these catalysts, the specific surface area after aging decreased by an average of $1-2 \mathrm{~m}^{2} / \mathrm{g}$. For example, at a concentration of $1.5 \mathrm{wt} \%$ of potassium, it decreased from about 9.5 to $8.3 \mathrm{~m}^{2} / \mathrm{g}$, and at a concentration of $2.9 \mathrm{wt} . \%$ of potassium it decreased from about 5.5 to $3.7 \mathrm{~m}^{2} / \mathrm{g}$. The most prominent decrease in the specific surface area, by about half, was observed for a catalyst containing 3.5 wt.\% of potassium.

Catalytic activity measured at $450{ }^{\circ} \mathrm{C}$ during the ammonia synthesis reaction carried out under a pressure of $10 \mathrm{MPa}$ for a series of COMON catalysts is shown in Figure 4. Considering fresh catalysts, the one containing $0.2 \mathrm{wt} . \%$ of potassium was less active than the non-promoted COMON catalyst. However, with increasing potassium concentration, the catalytic activity grew and its highest value was observed at $1.3 \%$ of potassium. In comparison to the non-promoted COMON catalyst, the activity at maximum was about $50 \%$ higher. The potassium concentration greater than $1.3 \%$ resulted in a drop in catalytic activity. Catalysts containing $2.9 \%$ and $3.5 \%$ potassium demonstrated very low activity, only about $25 \%$ and $10 \%$ compared to the non-promoted COMON catalyst, respectively.

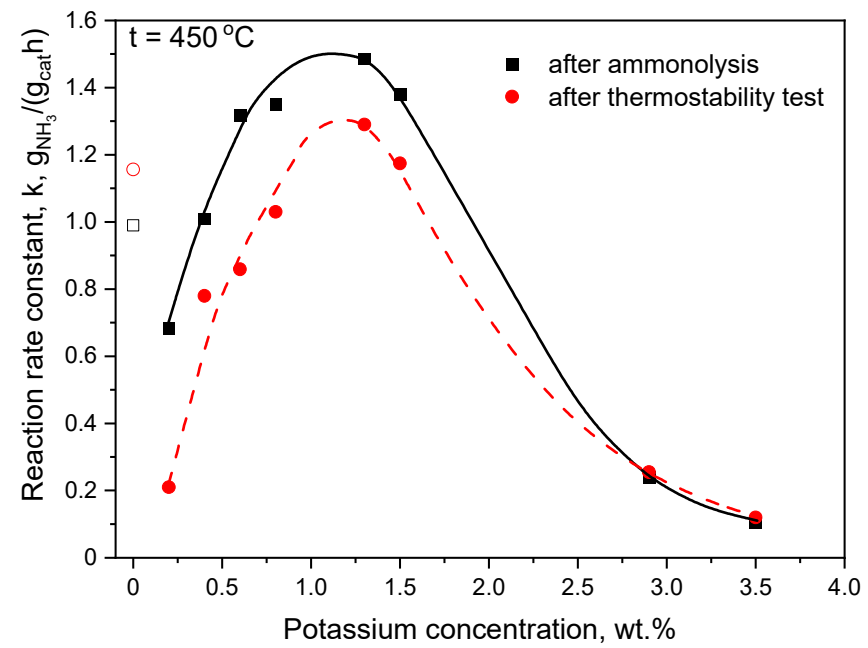

Figure 4. Catalytic activity of COMON catalysts as a function of the potassium concentration measured after ammonolysis and after the thermostability test. Catalytic tests were carried out at $450{ }^{\circ} \mathrm{C}$ under $10 \mathrm{MPa}$. Lines are given for eye guidance.

The second activity test was performed after the thermostability test. The catalytic activity of the non-promoted COMON catalyst increased by about $15 \%$. After the thermostability test, significant deactivation was observed for most of the potassium-promoted COMON catalysts. The catalysts containing $1.3 \mathrm{wt} . \%$ and $1.5 \mathrm{wt} . \%$ of potassium were still more active than the reference material. However, a decrease of about $15 \%$ of their initial activity occurred. In the case of the catalysts containing 2.9 wt. $\%$ and 3.5 wt.\% of potassium, which were barely active already in the initial stage, the catalytic activity remained virtually unchanged.

\section{Discussion}

The literature considering the early studies of cobalt molybdenum nitride catalysts indicates that the compound described by $\mathrm{Co}_{3} \mathrm{Mo}_{3} \mathrm{~N}$ stoichiometry is expected to be the only ternary nitride obtained after ammonolysis of the precursor [15]. Metallic cobalt and molybdenum nitride, $\mathrm{Mo}_{2} \mathrm{~N}$, were observed as intermediates and as decomposition products after prolonged gas and heat treatment [7,15,31]. However, in our previous studies [18-21] the occurrence of two cobalt molybdenum nitrides: $\mathrm{Co}_{3} \mathrm{Mo}_{3} \mathrm{~N}$ and $\mathrm{Co}_{2} \mathrm{Mo}_{3} \mathrm{~N}$ was observed. 
Unlike previous reports by Kojima and Aika [24], the decomposition products (metallic cobalt or molybdenum nitride $\mathrm{Mo}_{2} \mathrm{~N}$ ) were not observed after the thermostability test. Earlier reports indicate that the formation of the $\mathrm{Co}_{2} \mathrm{Mo}_{3} \mathrm{~N}$ phase required special treatment [32]. However, a detailed review of older reports indicated that the $\mathrm{Co}_{2} \mathrm{Mo}_{3} \mathrm{~N}$ phase also occurred after ammonolysis, but was not adequately identified [33].

In the study focused on the influence of chromium salts on the formation of similar mixtures of cobalt molybdenum nitrides [20], two possible ways of $\mathrm{Co}_{2} \mathrm{Mo}_{3} \mathrm{~N}$ formation were considered. The $\mathrm{Co}_{2} \mathrm{Mo}_{3} \mathrm{~N}$ phase was considered as a product of the decomposition of $\mathrm{Co}_{3} \mathrm{Mo}_{3} \mathrm{~N}$ or as an intermediate on the path to $\mathrm{Co}_{3} \mathrm{Mo}_{3} \mathrm{~N}$ formation. Since this phase disappears with increasing ammonolysis temperature, it is not observed in $\mathrm{Co}_{3} \mathrm{Mo}_{3} \mathrm{~N}$ decomposition products either, it is supposedly an intermediate product. This is in agreement with our previous study [22], in which data obtained by the in situ XRD method during the non-promoted precursor activation process at $700{ }^{\circ} \mathrm{C}$ in the presence of a mixture of inert gas and ammonia was analyzed. $\mathrm{Co}_{2} \mathrm{Mo}_{3} \mathrm{~N}$ is the first reaction product, which transforms into stable $\mathrm{Co}_{3} \mathrm{Mo}_{3} \mathrm{~N}$ by further reconstruction with cobalt atoms.

In the present study, the preparation parameters: relatively low final ammonolysis temperature $\left(700^{\circ} \mathrm{C}\right)$ and high heating rate $\left(10^{\circ} \mathrm{C} / \mathrm{min}\right)$ appear to promote the formation of the $\mathrm{Co}_{2} \mathrm{Mo}_{3} \mathrm{~N}$ compound. Herein, a notable variation of the phase composition of the catalysts was observed. The precursors of the samples are virtually identical, and the change in $\mathrm{Co}_{2} \mathrm{Mo}_{3} \mathrm{~N}$ concentration is attributed to the only variable parameter, the potassium concentration. The analogous effect of chromium salt addition was previously reported [20]. The content of the $\mathrm{Co}_{2} \mathrm{Mo}_{3} \mathrm{~N}$ phase decreases with increasing concentration of chromium in the material. In the case of the potassium admixture, this dependence is more complex. Starting from small concentrations of potassium, the weight fraction of $\mathrm{Co}_{2} \mathrm{Mo}_{3} \mathrm{~N}$ phase grows, with the maximum at about $0.8 \mathrm{wt} . \%$ of potassium. The excessive potassium content leads to a decrease in $\mathrm{Co}_{2} \mathrm{Mo}_{3} \mathrm{~N}$ concentration. The mechanism that explains the observed influence of potassium on the phase composition of the studied samples remains unknown.

The catalytic activity of COMON catalysts in the process of ammonia synthesis is high. The highest reaction rate constant observed for the catalyst containing $1.3 \mathrm{wt} . \%$ of potassium was $1.5 \mathrm{~g}_{\mathrm{NH}_{3}} \cdot \mathrm{g}^{-1} \cdot \mathrm{h}^{-1}$. It is approximately twice as high as the reaction rate constant observed under identical process conditions for industrial iron catalysts $\left(0.6 \div 0.7 \mathrm{~g}_{\mathrm{NH}_{3}} \cdot \mathrm{g}^{-1} \cdot \mathrm{h}^{-1}\right)$ [34]. The optimal potassium concentration corresponds well to the studies we previously reported on COMON catalysts at $400{ }^{\circ} \mathrm{C}[18,27]$. A comparable amount of potassium promoter was also claimed as optimal in the report by Kojima and Aika [15]. In their study, the catalyst containing approximately $1.2 \mathrm{wt} . \%$ of potassium (that is, $0.05 \mathrm{~mol} \mathrm{~K}$ per mol Mo) was the most active one. It must be stated that the latter study was carried out under lower pressures (between 0.1 MPa and 3.1 MPa).

The detrimental influence of excessive potassium admixture confirms earlier reports $[15,18]$. Especially beyond $2.9 \mathrm{wt} . \%$ of potassium, the catalytic activity of COMON catalysts was very low. An excess of alkali metal was supposed to prevent the proper development of the catalyst surface [15]. The surface area of cobalt molybdenum nitride mixtures was prominently affected by the potassium content. It decreased by about $30 \%$ compared to the potassium-free COMON catalyst. It also varied considerably with potassium concentration. The optimal potassium content in COMON catalysts needed for the development of the highest specific surface area is ambiguous. The values of this parameter observed at $0.8 \mathrm{wt} . \%$ and $1.3 \mathrm{wt} . \%$ are relatively close to each other, and the optimal potassium concentration supposedly lies between them.

The influence of the potassium content on the activity of the COMON catalysts is analogous to that observed for potassium-promoted iron catalysts, both fused [35] and supported [36]. Low and very high potassium concentrations in these catalysts also result in a relatively low catalytic activity. We suppose that this is a general property resulting from the presence of potassium atoms on the surface of the catalysts. Alkali metals are assumed 
to affect the electronic properties of the surface active sites. However, the possibility that potassium modifies the structure of catalysts should not be overlooked [37,38].

The loss of activity after the thermostability test correlates well with the decrease of the surface area, which was observed for all catalysts, apart from the unpromoted one. Because the only variable between the studied materials was the potassium concentration, this phenomenon is associated with the difference in the structure of the catalysts, which apparently is the change of $\mathrm{Co}_{2} \mathrm{Mo}_{3} \mathrm{~N}$ and $\mathrm{Co}_{3} \mathrm{Mo}_{3} \mathrm{~N}$ concentrations.

\section{Materials and Methods}

\subsection{Precursor Synthesis}

Catalyst precursors were obtained using the method described in the previous work [18]. Briefly, water solutions of cobalt nitrate, $\mathrm{Co}\left(\mathrm{NO}_{3}\right)_{2} \cdot 6 \mathrm{H}_{2} \mathrm{O}$, and ammonium molybdate, $\left(\mathrm{NH}_{4}\right)_{6} \mathrm{Mo}_{7} \mathrm{O}_{24} \cdot 4 \mathrm{H}_{2} \mathrm{O}$, were stirred and heated to about $90{ }^{\circ} \mathrm{C}$. These solutions were mixed, while the $\mathrm{pH}$ of the resulting solution was controlled by addition of a $25 \%$ aqueous ammonia solution $\left(\mathrm{NH}_{3} \cdot \mathrm{H}_{2} \mathrm{O}\right)$ to remain at $\mathrm{pH}=5.5$. A purple-blue precipitate was isolated by vacuum filtration, rinsed three times with distilled water and once with ethanol, then dried overnight at $150{ }^{\circ} \mathrm{C}$. Potassium-promoted samples were obtained by impregnation of the precipitate in aqueous solutions of potassium nitrate, $\mathrm{KNO}_{3}$, in a vacuum evaporator at $60{ }^{\circ} \mathrm{C}$. The concentration of potassium ions in solution was chosen as such to obtain the potassium concentration in the final, nitrided form of catalysts in the range $0.2-3.5 \%$ by weight.

\subsection{Nitriding of Precursor}

The active form of the catalysts was synthesized via the reduction process of the oxidized precursor under the flow of pure ammonia in a horizontal steel reactor placed inside an electric oven and then following the procedure described elsewhere $[31,39]$. Approximately $6 \mathrm{~g}$ of the oxidized precursor powder was placed in a ceramic boat. After flushing the reactor with pure ammonia, the precursor was heated under flowing ammonia gas $\left(\mathrm{NH}_{3}\right.$ flow $-250 \mathrm{sccm}$, heating rate $-10^{\circ} \mathrm{C} / \mathrm{min}$., maximum temperature- $\left.700{ }^{\circ} \mathrm{C}\right)$. The sample was kept under ammonia flow at $700{ }^{\circ} \mathrm{C}$ for $6 \mathrm{~h}$ and then cooled to room temperature. The resulting fine-crystalline substrate was pyrophoric, and therefore each sample was left overnight in the flow of oxygen/nitrogen mixture (1:100) for passivation. The materials were then removed from the reactor and pressed into pellets, which were subsequently crushed and sieved. The 1.0-1.2 $\mathrm{mm}$ grain fraction was selected and used for the activity experiments.

\subsection{Material Characterization}

The phase composition of the materials was analyzed by powder X-ray diffraction (XRD). The Philips X'pert PRO MPD diffractometer was used in Bragg-Brentano geometry, with a $\mathrm{Cu}$ radiation source. To avoid fluorescence effects, a graphite monochromator was used. Phase identification was performed with the use of the ICDD PDF-4+ database [40]. A full-pattern fit based on the Rietveld method, using the formalism described by Hill and Howard [41], was applied to calculate the weight fractions of the crystallographic phases identified in the material. A semi-automatic Rietveld refinement procedure included in the HighScore Plus software [42] by PANalytical B.V. was used. All the data required for initialization of the Rietveld refinement were retrieved from the ICDD database. During the Rietveld refinement, the scale factor, unit cell parameters, full width at half maximum, and peak shape parameters of the phases have been refined. The pseudo-Voigt function was used.

The specific surface area of the nitrided samples was measured by the volumetric method using the $\mathrm{N}_{2}$ adsorption-desorption isotherm at $77 \mathrm{~K}$. The Quantachrome Quadrasorb SI-Kr/MP apparatus was used. Before measurements, the samples were degassed in vacuo for $6 \mathrm{~h}$ at $400{ }^{\circ} \mathrm{C}$. The specific surface area was calculated using the BrunauerEmmett-Teller (BET) equation. It was performed using commercial QuadraWin software. 


\subsection{Catalytic Activity Tests}

Catalytic activity tests were performed in the apparatus described in detail elsewhere [43]. The equipment consists of a 6-channel high-pressure steel reactor with a gas purification stage and enables the synthesis of ammonia under the pressure up to $10 \mathrm{MPa}$ at a temperature reaching $650{ }^{\circ} \mathrm{C}$. The $1 \mathrm{~g}$ samples of nitrided catalysts were placed inside the reactor in separate channels. Cobalt molybdenum nitride without alkali admixture was used as a reference sample. The samples were activated under a flowing reactant mixture $\left(\mathrm{N}_{2}+3 \mathrm{H}_{2}, 330 \mathrm{sccm}, 0.1 \mathrm{MPa}\right)$ according to the following temperature program: $2 \mathrm{~h}$ at $3500^{\circ} \mathrm{C}, 3 \mathrm{~h}$ at $400{ }^{\circ} \mathrm{C}, 14 \mathrm{~h}$ at $450{ }^{\circ} \mathrm{C}$ and $24 \mathrm{~h}$ at $500{ }^{\circ} \mathrm{C}$. This procedure is intended to remove the superficial oxide layer formed on the surface of catalysts during the passivation stage. The ammonia synthesis process was carried out with parameters as follows: pressure-10 $\mathrm{MPa}$, gas reactants flow- $330 \mathrm{sccm}$, temperature $-450{ }^{\circ} \mathrm{C}$. The ammonia concentration was measured in the outlet gas stream using a Siemens ULTRAMAT 6 NDIR (non-dispersive infrared absorbance) gas analyzer. The reaction rate constants of the ammonia synthesis reaction was calculated for each catalyst utilizing the modified Tiemkin-Pyzhev equation described elsewhere [44].

After the first activity test, all catalysts were heated in the reactor under a flowing ammonia-hydrogen mixture at $650^{\circ} \mathrm{C}$ for $12 \mathrm{~h}$. This procedure was intended to simulate the long-run action of the catalyst and is further referred to as thermostability test. Subsequently, the temperature was lowered to $450{ }^{\circ} \mathrm{C}$ and the activity test was repeated under identical conditions as described above.

\section{Conclusions}

Catalysts based on the mixture of $\mathrm{Co}_{3} \mathrm{Mo}_{3} \mathrm{~N}$ and $\mathrm{Co}_{2} \mathrm{Mo}_{3} \mathrm{~N}$ phases are highly active in the process of ammonia synthesis. Admixture of potassium compounds promotes the catalytic activity. Additionally, the phase composition of the catalysts is affected by the potassium content. After the thermostability test, the potassium-free catalyst remains virtually unchanged. Potassium-promoted catalysts lose catalytic activity as a result of the decrease of their surface area. The characteristic shape of the relation between potassium concentration and all of the measured parameters was observed for fresh catalysts as well as after the thermostability test. The maximum of the surface area and activity was observed for the catalysts with the greatest concentration of the $\mathrm{Co}_{2} \mathrm{Mo}_{3} \mathrm{~N}$ phase, around $0.8-1.3 \mathrm{wt} . \%$ of potassium.

Author Contributions: Conceptualization; methodology; investigation; writing-original draft preparation; writing - review and editing; visualization; project administration; funding acquisition, P.A. Investigation; writing —original draft preparation; writing—review and editing; visualization, W.C. Conceptualization: methodology; investigation; writing—original draft preparation; writing-review and editing; visualization; supervision, D.M. All authors have read and agreed to the published version of the manuscript.

Funding: The scientific work was financed by the Polish National Centre for Research and Development, grant "Lider", project No. LIDER/10/0039/L-10/18/NCBR/2019 (Paweł Adamski); and the National Science Centre, Poland, grant "Preludium Bis", project No. 2019/35/O/ST5/02500 (Wojciech Czerwonko).

Data Availability Statement: Not applicable.

Conflicts of Interest: The authors declare no conflict of interest.

\section{References}

1. Hargreaves, J.S.J. Nitrides as ammonia synthesis catalysts and as potential nitrogen transfer reagents. Appl. Petrochem. Res. 2014, 4, 3-10. [CrossRef]

2. Kotarba, A.; Dmytrzyk, J.; Raróg-Pilecka, W.; Kowalczyk, Z. Surface heterogeneity and ionization of Cs promoter in carbon-based ruthenium catalyst for ammonia synthesis. Appl. Surf. Sci. 2003, 207, 327-333. [CrossRef]

3. Karolewska, M.; Truszkiewicz, E.; Mierzwa, B.; Kępiński, L.; Raróg-Pilecka, W. Ammonia synthesis over cobalt catalysts doped with cerium and barium. Effect of the ceria loading. Appl. Catal. A Gen. 2012, 445-446, 280-286. [CrossRef] 
4. Dongil, A.B. Recent Progress on Transition Metal Nitrides Nanoparticles as Heterogeneous Catalysts. Nanomaterials 2019, 9, 1111. [CrossRef]

5. Boisen, A.; Dahl, S.; Jacobsen, C.J.H. Promotion of Binary Nitride Catalysts: Isothermal $\mathrm{N}_{2}$ Adsorption, Microkinetic Model, and Catalytic Ammonia Synthesis Activity. J. Catal. 2002, 208, 180-186. [CrossRef]

6. She, Y.; Tang, B.; Li, D.; Tang, X.; Qiu, J.; Shang, Z.; Hu, W. Mixed Nickel-Cobalt-Molybdenum Metal Oxide Nanosheet Arrays for Hybrid Supercapacitor Applications. Coatings 2018, 8, 340. [CrossRef]

7. Hada, K.; Tanabe, J.; Omi, S.; Nagai, M. Characterization of cobalt molybdenum nitrides for thiophene HDS by XRD, TEM, and XPS. J. Catal. 2002, 207, 10-22. [CrossRef]

8. Hada, K.; Nagai, M.; Omi, S. Characterization and HDS activity of cobalt molybdenum nitrides. J. Phys. Chem. B 2001, 105, 4084-4093. [CrossRef]

9. Logan, J.W.; Heiser, J.L.; McCrea, K.R.; Gates, B.D.; Bussell, M.E. Thiophene hydrodesulfurization over bimetallic and promoted nitride catalysts. Catal. Lett. 1998, 56, 165-171. [CrossRef]

10. Furimsky, E. Metal carbides and nitrides as potential catalysts for hydroprocessing. Appl. Catal. A Gen. 2003, 240, 1-28. [CrossRef]

11. Chen, X.; Zhang, T.; Zheng, M.; Wu, Z.; Wu, W.; Li, C. The reaction route and active site of catalytic decomposition of hydrazine over molybdenum nitride catalyst. J. Catal. 2004, 224, 473-478. [CrossRef]

12. Shi, C.; Zhu, A.M.; Yang, X.F.; Au, C.T. NO Reduction with Hydrogen over Cobalt Molybdenum Nitride and Molybdenum Nitride: A Comparison Study. Catal. Lett. 2004, 97, 9-16. [CrossRef]

13. Kojima, R.; Aika, K.I. Cobalt molybdenum bimetallic nitride catalysts for ammonia synthesis. Part 2. Kinetic study. Appl. Catal. A 2001, 218, 121-128. [CrossRef]

14. Jacobsen, C.J.H.; Dahl, S.; Clausen, B.S.; Bahn, S.; Logadottir, A.; Norskov, J.K. Catalyst Design by Interpolation in the Periodic Table: Bimetallic Ammonia Synthesis Catalysts. J. Am. Chem. Soc. 2001, 123, 8404-8405. [CrossRef] [PubMed]

15. Kojima, R.; Aika, K.-I. Cobalt molybdenum bimetallic nitride catalysts for ammonia synthesis Part 1. Preparation and characterization. Appl. Catal. A Gen. 2001, 215, 149-160. [CrossRef]

16. Jacobsen, C.J.H. Novel class of ammonia synthesis catalysts. Chem. Commun. 2000, 1057-1058. [CrossRef]

17. Kojima, R.; Aika, K. Cobalt molybdenum bimetallic nitride catalysts for ammonia synthesis. Chem. Lett. 2000, $29,514-515$. [CrossRef]

18. Moszyński, D.; Jędrzejewski, R.; Ziebro, J.; Arabczyk, W. Surface and catalytic properties of potassium-modified cobalt molybdenum catalysts for ammonia synthesis. Appl. Surf. Sci. 2010, 256, 5581-5584. [CrossRef]

19. Adamski, P.; Nadziejko, M.; Komorowska, A.; Sarnecki, A.; Albrecht, A.; Moszyński, D. Chromium-modified cobalt molybdenum nitrides as catalysts for ammonia synthesis. Open Chem. 2019, 17, 127-131. [CrossRef]

20. Moszyński, D. Controlled phase composition of mixed cobalt molybdenum nitrides. Int. J. Refract. Met. Hard Mater. 2013, 41, 449-452. [CrossRef]

21. Moszyński, D.; Adamski, P.; Nadziejko, M.; Komorowska, A.; Sarnecki, A. Cobalt molybdenum nitrides co-promoted by chromium and potassium as catalysts for ammonia synthesis. Chem. Pap. 2018, 72, 425-430. [CrossRef]

22. Adamski, P.; Moszyński, D.; Komorowska, A.; Nadziejko, M.; Sarnecki, A.; Albrecht, A. Ammonolysis of Cobalt Molybdenum Oxides-In Situ XRD Study. Inorg. Chem. 2018, 57, 9844-9850. [CrossRef] [PubMed]

23. Liu, H. Ammonia Synthesis Catalysts: Innovation and Practice; World Scientific: Singapore, 2013.

24. Kojima, R.; Aika, K.I. Cobalt molybdenum bimetallic nitride catalysts for ammonia synthesis. Part 3. Reactant gas treatment. Appl. Catal. A 2001, 219, 157-170. [CrossRef]

25. Adamski, P.; Moszyński, D.; Nadziejko, M.; Komorowska, A.; Sarnecki, A.; Albrecht, A. Thermal stability of catalyst for ammonia synthesis based on cobalt molybdenum nitrides. Chem. Pap. 2019, 73, 851-859. [CrossRef]

26. Daisley, A.; Costley-Wood, L.; Hargreaves, J.S.J. The Role of Composition and Phase upon the Lattice Nitrogen Reactivity of Ternary Molybdenum Nitrides. Top. Catal. 2021, 73, 851-859. [CrossRef]

27. Nadziejko, M.; Adamski, P.; Moszyński, D. Doped cobalt-molybdenum catalysts for the ammonia synthesis. Przem. Chem. 2020, 99, 1454-1458. [CrossRef]

28. Moszyński, D.; Adamski, P.; Pelech, I.; Arabczyk, W. Cobalt-molybdenum catalysts doped with cesium for ammonia synthesis. Przem. Chem. 2015, 94, 1399-1403. [CrossRef]

29. Dry, M.E.; du Plessis, J.A.K.; Leuteritz, G.M. The Influence of Structural Promoters on the Surface Properties of Reduced Magnetite Catalysts. J. Catal. 1966, 6, 194-199. [CrossRef]

30. Raje, A.P.; O'Brien, R.J.; Davies, B.H. Effect of potassium promotion on iron-based catalysts for Fischer-Tropsch synthesis. J. Catal. 1998, 180, 36-43. [CrossRef]

31. Choi, J.-G.; Curl, R.L.; Thompson, L.T. Molybdenum Nitride Catalysts I. Influence of the Synthesis Factors on Structural Properties. J. Catal. 1994, 146, 218-227. [CrossRef]

32. Prior, T.J.; Battle, P.D. Facile synthesis of interstitial metal nitrides with the filled b-manganese structure. J. Solid State Chem. 2003, 172, 138-147. [CrossRef]

33. Alconchel, S.; Sapiña, F.; Beltran, D.; Beltran, A. Chemistry of interstitial molybdenum ternary nitrides $\mathrm{M}_{\mathrm{n}} \mathrm{Mo}_{3} \mathrm{~N}(\mathrm{M}=\mathrm{Fe}, \mathrm{Co}$, $\mathrm{n}=3 ; \mathrm{M}=\mathrm{Ni}, \mathrm{n}=2)$. J. Mater. Chem. 1998, 8, 1901-1909. [CrossRef]

34. Arabczyk, W.; Kałucki, K.; Kaleńczuk, R.J.; Śpiewak, Z.; Morawski, A.W.; Pajewski, R.; Ludwiczak, S.; Stołecki, K.; Janecki, Z. Badanie aktywności kontaktów żelazowych do syntezy amoniaku. Przem. Chem. 1986, 65, 532. 
35. Kowalczyk, Z.; Jodzis, S.; Środa, J.; Diduszko, R.; Kowalczyk, E. Influence of aluminium and potassium on activity and texture of fused iron Catalysts for ammonia synthesis. Appl. Catal. A Gen. 1992, 87, 1-14. [CrossRef]

36. Yan, P.; Guo, W.; Liang, Z.; Meng, W.; Yin, Z.; Li, S.; Li, M.; Zhang, M.; Yan, J.; Xiao, D.; et al. Highly efficient K-Fe/C catalysts derived from metal-organic frameworks towards ammonia synthesis. Nano Res. 2019, 12, 2341-2347. [CrossRef]

37. Spencer, M. On the rate-determining step and the role of potassium in the catalytic synthesis of ammonia. Catal. Lett. 1992, 13, 45-53. [CrossRef]

38. Arabczyk, W.; Narkiewicz, U.; Moszyński, D. Double-layer model of the fused iron catalyst for ammonia synthesis. Langmuir 1999, 15, 5785-5789. [CrossRef]

39. Bem, D.S.; Olsen, H.P.; zur Loye, H.-C. Synthesis, Electronic and Magnetic Characterization of the Ternary Nitride $\left(\mathrm{Fe}_{0.8} \mathrm{Mo}_{0.2}\right) \mathrm{MoN}_{2}$. Chem. Mater. 1995, 7, 1824. [CrossRef]

40. Gates-Rector, S.; Blanton, T. The Powder Diffraction File: A quality materials characterization database. Powder Diffr. 2019, 34, 352-360. [CrossRef]

41. Hill, R.; Howard, C. Quantitative phase analysis from neutron powder diffraction data using the Rietveld method. J. Appl. Crystallogr. 1987, 20, 467-474. [CrossRef]

42. Degen, T.; Sadki, M.; Bron, E.; König, U.; Nénert, G. The HighScore suite. Powder Diffr. 2014, 29, S13-S18. [CrossRef]

43. Arabczyk, W. The state of studies on iron catalyst for ammonia synthesis. Pol. J. Chem. Technol. 2005, 7, 8-17.

44. Arabczyk, W.; Moszyński, D.; Narkiewicz, U.; Pelka, R.; Podsiadły, M. Poisoning of iron catalyst by sulfur. Catal. Today 2007, 124, 43-48. [CrossRef] 